Kadek Deny Anjasmara, Nyoman Djinar Setiawina. Pengaruh Daya Tarik Wisata, Hotel.... 234

\title{
PENGARUH DAYA TARIK WISATA, HOTEL RESTORAN,BIRO PERJALANAN TERHADAP PENYERAPAN TENAGA KERJA DAN PENDAPATAN PERKAPITA
}

\author{
Kadek Deny Anjasmara ${ }^{1}$ \\ Nyoman Djinar Setiawina ${ }^{2}$
}

1,2Fakultas Ekonomi dan Bisnis Universitas Udayana (Unud), Bali, Indonesia

E-mail: kadekdenyanjasmara@gmail.com

\begin{abstract}
The Effect of Tourism Attractions, Hotel Restaurants, Travel Agencies on Labor Absorption and Per capita Income The purpose of this study is analyze:1) direct effect oftourist attraction, hotel restaurant, travel agency on employment. 2) direct effect oftourist attraction, hotel restaurant,travel agency and employment on percapita income. 3)indirect effects of tourist attraction, hotel restaurant,travel agencyon percapita income through employment. The analysis technique uses path analysis. Results of the simultaneous direct effecttourist attraction,hotel restaurant,travel agency on employmentis positive significant effect, and will have positive implications for tourism sector employment. The results of the simultaneous direct effect between tourist attraction, hotel restaurant, travel agency, and employment on income percapita had positive significant. The results of this analysis have implications for increasing percapita income in the districts / cities of the Province of Bali. The results of indirect effect of tourist attraction, hotel restaurant,travel agencyon the percapita income through employment with a causal step, Hotel restaurant and travel agency had a positive significant effect on percapita income. Effect of tourist attraction on percapita income through employmenthad positive influence not significant.
\end{abstract}

Keywords: tourist attraction; hotel-restaurant; travel agency; employment; percapita income.

\begin{abstract}
Abstrak: Pengaruh Daya Tarik Wisata, Hotel Restoran, Biro Perjalanan Terhadap Penyerapan Tenaga Kerja dan Pendapatan Perkapita. Penelitian ini bertujuan menganalisis: 1) pengaruh langsung DTW, Hotel Restoran, BPW terhadap 1 penyerapan tenaga kerja. 2) pengaruh langsung DTW, Hotel Restoran, BPW dan penyerapan tenaga kerja terhadap pendapatan perkapita. 3) pengaruh tidak langsung DTW, Hotel Restoran, BPW terhadap pendapatan perkapita melalui penyerapan tenaga kerja. Teknik analisis menggunakan teknik analisis jalur. Hasil analisis pengaruh langsung secara simultan DTW, Hotel Restoran, BPW terhadap Penyerapan tenaga kerja adalah berpengaruh positif dan signifikan, dan akan berimplikasi positif terhadap penyerapan tenaga kerja. Begitu pula dari uji analisis pengaruh langsung secara simultan antara DTW, Hotel Restoran, BPW, dan penyerapan tenaga kerja terhadap pendapatan perkapita di peroleh hasil positif dan signifikan. Hasil analisis ini berimplikasi terhadap peningkatan pendapatan perkapita masyarakat di kabupaten/kota Provinsi Bali. Hasil uji pengaruh tidak langsung DTW, Hotel Restoran, BPW terhadap pendapatan perkapita melalui variabel penyerapan tenaga kerja dengan pendekatan causal step di peroleh hasil, hotel restoran dan BPW memiliki pengaruh yang positif dan signifikan terhadap pendapatan perkapita. Selanjutnya pengaruh DTW terhadap pendapatan perkapita melalui penyerapan tenaga kerja memiliki pengaruh positif tidak signifikan.
\end{abstract}

Kata kunci: daya tarik wisata; hotel-restoran; biro perjalanan wisata; penyerapan tenaga kerja; pendapatan perkapita. 


\section{PENDAHULUAN}

Indonesia merupakan salah satu Negara yang memiliki berbagai macam potensi kepaiwisataan baik wisata alam atupun wisata budaya, hal ini disebabkan karena Indonesia memiliki bermacam-macam suku, adat istiadat, budaya serta letak giegrafisnya yang sangat strategis dengan berbagai pulau yang terhampar dari sabang sampai Merauke (Artana Yasa, 2015).Dengan potensi wisata yang dimiliki tersebut, maka sector pariwisata dapat dijadikan sebagai salah satu sector andalan dalam bidang pertumbuhan ekonomi dan penciptaan peluang kerja. Ini sejalan dengan yang dinyatakan Rukini dkk (2015) yaitu Sektor pariwisata diharapkan dapat menggerakan ekonomi rakyat karena dianggap sektor yang paling siap dari segi fasilitas, sarana dan prasarana dibandingkan dengan sektor usaha lainnya. Dianggap sebagai sektor yang paling siap dari segi fasilitas maupun saranan dan prasarana maka sektor pariwisata di harpakan akan mampu menciptakan peluang kerja dan mampu pula menyerap tenaga kerja yang banyak sehingga dapat berperan dalam meningkatkan pendapatan perkapita dalam rangka mensejahterakan masyarakat. Pleanggra et al (2012:1). Pakar ekonomi memperkirakan sektor pariwisata akan menjadi salah satu kegiatan yang penting pada abad ke- 21 dalam perekonomian suatu negara, sehingga menurut Samimi dkk (2011), pariwisata telah menjadi salah satu sektor ekspor yang paling signifikan di banyak negara berkembang. Sektor pariwisata mempunyai peran dan fungsi strategis dalam pembangunan, di samping sebagai penghasil devisa bagi negara dan menghasilkan pendapatan mendekati tingkat potensial atau tingkat yang diinginkan bagi daerah juga dapat meningkatkan pertumbuhan perekonomian masyarakat (Lewis, 2006).

Sebagai industri padat karya, pariwisata menyediakan berbagai macam pekerjaan, sehingga dapat menyerap tenaga kerja lebih banyak guna menunjang keberhasilan industri pariwisata itu sendiri (Kibara et al, 2012
). Keberhasilan pembangunan sektor pariwisata suatu wilayah dapat digambarkan dengan seberapa banyak wisatawan yang berkunjung ke wilayah tersebut, begitu pula sebaliknya (Nursyamsi, 2005). Untuk melihat keuntungan pariwisata secara ekonomi maka dapat dilihat dari jumlah wisatawan dan rata-rata belanja wisatawan yang berkunjung ke daerah tujuan wisata (Nicely dan Palakurthi, 2012) Untuk itu dalam mengembangkannya hendaknya dilakukan secara terencana,hati-hati melalui analisis yang cermat, karena sektor pariwisata merupakan sector yang terintegrasi dengan sector-sektor lainnya.Senada dengan apa yang di katakan oleh Pelakurthi, dimana menurut Mostafa dan Shah Alam Kabir Pramanik (2015), sektor pariwisata merupakan sektor yang terintergrasi yang meliputi budaya, keindahan pemandangan, tempat arkeologi dan sejarah, sosial politik dan pembangunan infrastruktur.

Sebagai salah satu sector perekonomian dan pencipta lapangan pekerjaan, sector pariwisata perlu dikembangkan dan dilanjutkan melalui pemanfaatan secara maksimal potensipotensi wisata yang dimiliki oleh setiap daerah, menjadi destinasi-destinasi wisata (Kamal dan Shah, 2015). Berkembangnya kegiatan kepariwisataan akan mendorong muncul dan terciptanya Daya Tarik Wisata baru dan kegiatan usaha-usaha baru sebagi penunjang kegiatan kepariwisataan, seperti usaha sarana akomodasi, restoran-restoran, perusahaan biro perjalanan, toko-toko cinderamata, jasa pemandu wisata dan lain sebagainya, sehingga dalam mengembangkan sektor pariwisata tentunya diperlukan strategi yang ampuh yaitu dengan melakukan promosi terhadap potensi wisata yang ada (Ekanayake and Aubrey, 2012). Muncul dan terciptanya usaha-usaha dan Daya Tarik Wisata baru di sector kepariwisataan diharapkan mampu meningkatkan pertumbuhan ekonomi dan peluang kerja bagi pencari kerja serta meningkatkan kesejahteraan masyarakat dan secara tidak langsung akan mampu meningkatkan pendapatan perkapita 
masyarakatnya. Disamping itu menurut Waskito (2013), pariwisata juga di anggap sebagai salah satu industri yang dapat menyediakan pertumbuhan ekonomi yang cepat dalam kesempatan kerja, pendapatan, taraf hidup, serta mengaktifkan sektor produksi lain di dalam negara penerimaan wisatawan.

Pulau Bali merupakan salah satu provinsi yang ada di Indonesia.Selama berabad-abad, Bali terkenal sebagai daerah penghasil padi.Namun satu dekade lalu industri pariwisata merupakan penerimaan terbesar yang diterima (Bendesa dan Sukarsa, 2012).Provinsi Bali merupakan daerah yang terkenal sebagai daerah tujuan pariwisata, sektor pariwisata menjadi tulang punggung pertumbuhan ekonomi di Bali. Provinsi Bali dikenal sebagai daerah tujuan wisatawan karena memiliki keindahan alam,budaya, adat istiadat dan kegiatan keagamaan yang unik (Setyadhi, 2012). Sebagai salah satu daerah tujuan wisata dunia yang mengandalkan keunikan budaya dan adat istiadatnya serta keindahan alamnya sehingga Pulau Bali sangat digemari oleh wisatawan mancanegara dan domestic sebagai destinasi wisata yang favorit untuk dikunjungi. Keberhasilan dan Berkembangnya kegiatan kepariwisataan di Bali sebagai salah satu generator pembangunan perekonomian maka sector pariwisata diseluruh kabupaten/kota yang ada di Bali menjadi sektor yang sangat penting dalam pembangunan perekonomian dalam rangka meningkatkan kualitas kehidupan masyarakatnya melalui peningkatan pendapatan perkapita disamping sebagai penyedia lapangan kerja bagi pencari kerja. Agar mampu menjadi sektor andalan dalam pembangunan perekonomian dan juga sebagai penyerap tenaga kerja yang banyak dalam rangka meningkatkan kesejahteraan masyarakat sekaligus untuk meningkatkan pendapatan perkapita masyarakat maka provinsi Bali harus mampu mendorong setiap kabupaten-kota mengembangkan potensi wisata yang ada di wilayahnya dalam rangka meningkatkan kunjungan wisatawan ke obyek- obyek wisata yang dimiliki oleh masing-masing daerah.

Lie (2004) menyatakan bahwa perkembanganindustri pariwisata suatu daerah sangat bergantung kepada jumlah wisatawan yang datangOleh karena jumlah kunjungan wisatawan merupakan salah satu indicator keberhasilan mengembangkan sektor pariwisata dalam rangka menjadikan sektor pariwisata sebagai salah satu sector ekonomi andalan diluar minyak dan gas. Agar sektor pariwisata dapat menjadi sektor perekonomian andalan dalam rangka penyerapan tenaga kerja dan peningkatan pendapatan perkapita disektor pariwisata maka kunjungan wisatawan ke Pulau Bali diharapkan di masing-masing wilayah kabupaten-kota memiliki kecenderungan meningkat dari tahun ke tahun (Shimer, 2005)

Sebagai gambaran bahwa Provinsi Bali merupakan salah satu tujuan destinasi wisata yang favorit dan menarik untuk dikunjungi baik oleh wisatawan mancanegara maupun wisatawan domestic maka berikut dapat disajikan data tentang jumlah perkembangan kunjungan wisatawan mancanegara dan domestic seperti digambarkan pada grafik 1.

Berdasarkan grafik 1 dapat diketahui bahwa kunjungan wisatawan domestic dari tahun 2013 ke tahun 2014 menunjukan trend yang menurun, hal ini disebabkan karena pada periode tahun 2013 ke tahun 2014 merupakan tahun politik sehingga banyak wisatawan domestic yang menunda kegiatan berwisatanya, sedangkan kunjungan wisatawan domestic dari tahun 2014 sampai dengan tahun 2017 menunjukan tren peningkatan yang cukup signifikan dari tahun ke tahun kecuali untuk tahun 2016 ke tahun 2017 peningkatanya relaiif kecil, hal ini disebabkan pada tahun 2017 terjadi bencana meletusnya gunung Agung . Peningkatan kunjungan wisatawan domestic ini disebabkan adanya situasi politik dan keamanan yang relative setabil pasca tahun politik ,sehingga mendorong orang untuk melakukan perjalanan wisata, dengan rata-rata 
Grafik 1.

Jumlah Kunjungan Wisatawan mancanegara dan domestic ke Provinsi Bali dari Tahun 2013-2017

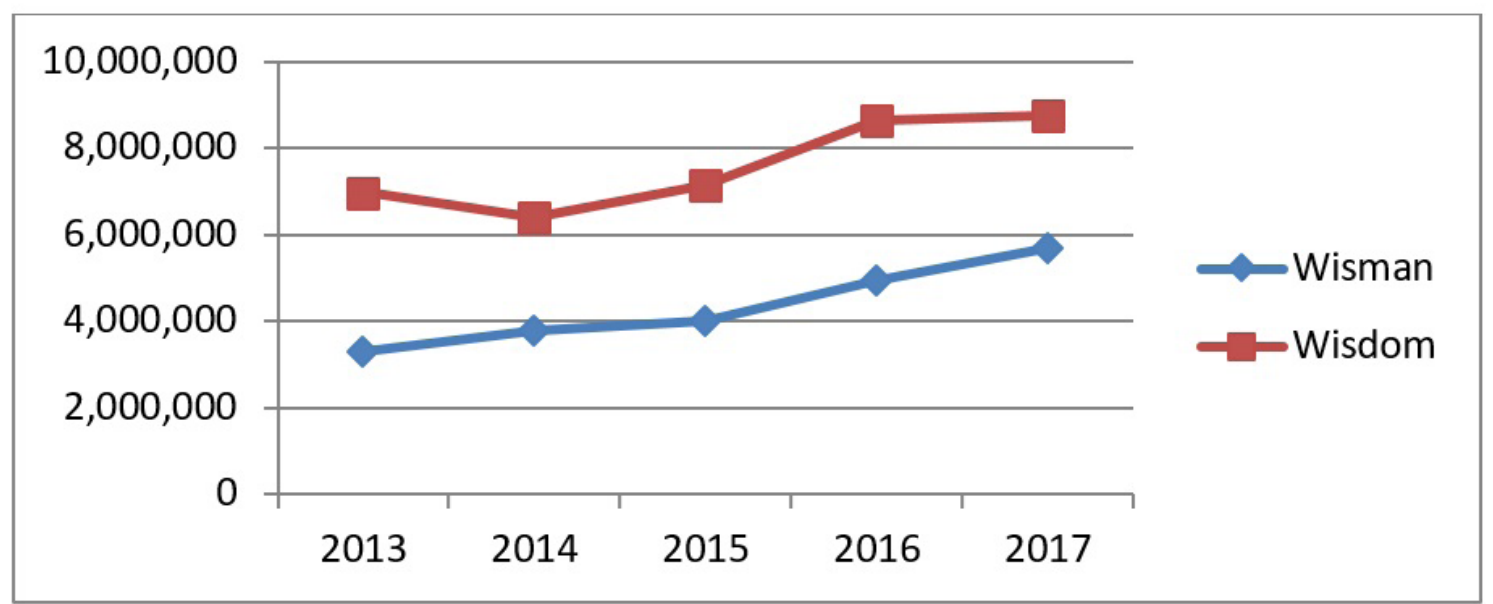

Sumber: Badan Pusat Statistik Provinsi Bali, 2017

jumlah kunjungan wisatawan domestic dalam lima tahun terakhir (2013-2017) yaitu sebanyak 7.580 .051 orang setiap tahunnya.

Berdasarkan grafik 1 , dapat pula diketahui jumlah kunjungan wisatawan mancanegara ke Provinsi Bali selama lima tahun terakhir (dari tahun 2013 sampai dengan 2017) menunjukan tren yang meningkat setiap tahunnya akan tetapi tren peningkatan jumlah kunjungan wisatawan mancanegara pada tahun 2015 tidak begitu signifikan jika dibandingkan dengan tahun-tahun lainnya. Kecilnya kenaikan kunjungan wisatawan mancanegara pada tahun 2015, disebabkan oleh karena adanya peristiwa bencana gunung meletus dan terror bom di Paris, sehingga banyak wisatawan mancanegara yang mengurungkan niatnya untuk mengunjungi Bali dalam melakukan kegiatan wisatanya

Selanjutnya pada tahun 2016 sampai denga tahun 2017 terjadi peningkatan kunjungan wisatawan mancanegara yang cukup signifikan, hal ini disebabkan banyaknya even-even internasiaonal yang diadakan di Bali seperti, festival -festival kesenian dan olah raga,dengan rata-rata jumlah kunjungan wisatawan mancanegara dalam lima tahun terakhir (20132017) yaitu sebanyak 4.336 .749 orang.

Banyaknya jumlah wisatawan mancanegara yang berasal dari daratan Asia (non Asean) seperti wisatawan China, Korea, Jepang yang berkunjung ke berbagai Daya Tarik Wisata yang ada di Kabupaten/Kota di Provinsi Bali ,hal ini disebabkan karena pertumbuhan perekonomian pada Negara-negara tersebut relative baik sehingga banyak warga negaranya untuk mengisi liburannya dengan berwisata keluar negeri seperti ke Bali.

Berdasrkan grafik 2 tersebut dapat dijelaskan bahwa dari tahun 2013 ke tahun 2014 terjadi penurunan jumlah Daya Tarik Wisata yang cukup signifikan, bahkan dari tahun 2014 ke tahun 2015 terjadi pertumbuhan yang stagnan hal ini disebabkan karena dampak tidak signifikannya pertumbuhan jumlah kunjungan wisatawan baik wisatawan domestic maupun wisatawan mancanegara yang datang ke Bali pada tahun tersebut, sehingga ada sebagian DayaTarik Wisata yang ada di berbagai Kabupaten/Kota di Provinsi Bali yang tidak berperasi atau ditutup. Kondisi ini berbanding terbalik jika dilihat dari tahun 2015 ke tahun 2017, dimana pada tahun-tahun tersebut terjadi pertumbuhan jumlah Daya Tarik Wisata mengalami pertumbuhan yang meningkat secara signifikan, hal ini sejalan dengan pertumbuhan jumlah kunjungan wisatawan ke Provinsi Bali. 
Grafik 2.

\section{Perkembangan Jumlah Daya Tarik Wisata di Provinsi Bali Pada tahun 2013-2017}

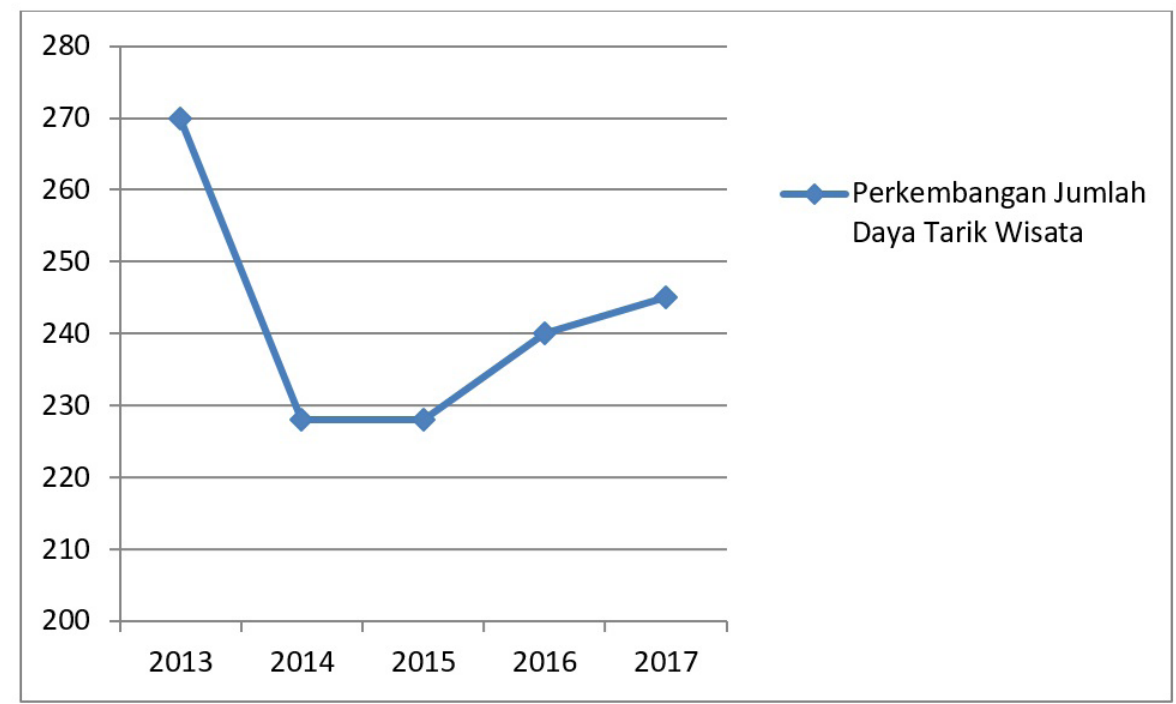

Sumber: Badan Pusat Statistik Provinsi Bali, 2017

Disamping

daya tarik wisata sebagai akibat dari meningkatnya kunjungan wisatawan juga mendorong tumbuh dan berkembangnya berbagai industry kepariwisataan, seperti berkembangnya fasilitas-fasilitas atau sarana dan prasarana pendukung guna menunjang kegiatan kepariwisataan. Berbagai industrya kepariwisataan yang berkembang diantaranya adalah sarana akomodasi seperti hotel,restoran, dan biro perjalanan wisata. Sebagai gambaran berkembang dan tumbuhnya sarana akomodasi seperti hotel dan restoran di Provinsi Bali dapat di sajikan dalam bentuk grafik,yaitu seperti terlihat pada grafik 3 tentang Perkembangan Jumlah Hotel Bintang, Non Bintang dan Restoran di Provinsi Bali.

Berdasarkan grafik 3 dapat diketahui bahwa jumlah restoran yang ada di Provinsi Bali dari tahun 2013 sampai dengan tahun 2017 menunjukan jumlah yang cenderung meningkat dari tahun ke tahun, dengan peningkatan jumlah restoran yang cukup signifikan terjadi pada tahun 2013 ke tahun 2014. Untuk hotel katagori berbintang dari tahun 2013 sampai dengan tahun 2017 menunjukkan perkembangannya yang berfluktuatif dengan perkembangan yang tidak begitu signifikan, sedangkan untuk hotel katagori non bintang dari tahun 2013 ke tahun 2016 jumlahnya cenderung meningkat, tetapi pada tahun 2017 menunjukan penurunan yang cukup sinifikan dari tahun sebelumnya, hal ini disebabkan karena tingkat hunian pada hotel non bintang relative rendah sehingga ada beberapa hotel non bintang yang menutup usahanya .

Perkembangan jumlah biro perjalanan wisata selama lima tahun terakhir (2013-2017) di Provinsi Bali dapat digambarkan seperti grafik 4. Dari berbagai sarana dan prasarana pariwisata, sarana akomodasi perhotelan dan restorandan Biro Perjalan Wisata di pandang sebagai sarana kepariwisataan yang sangat penting. Hal ini di sebabkan sarana akomodasi di sektor perhotelan dan restoran serta Biro Perjalanan Wisata adalah hal yang sangat mutlak di perlukan dalam menunjang kelancaran kegiatan kepariwisataaan di masing-masing wilayah kabupaten/kota di Provinsi Bali.

Sebagai sarana pokok dalam kegiatan kepariwisataan keberadaan industri perhotelan 
Grafik 3.

Perkembangan Jumlah Hotel Bintang dan Non Bintang dan Restoran di Provinsi Bali Pada tahun 2013-2017

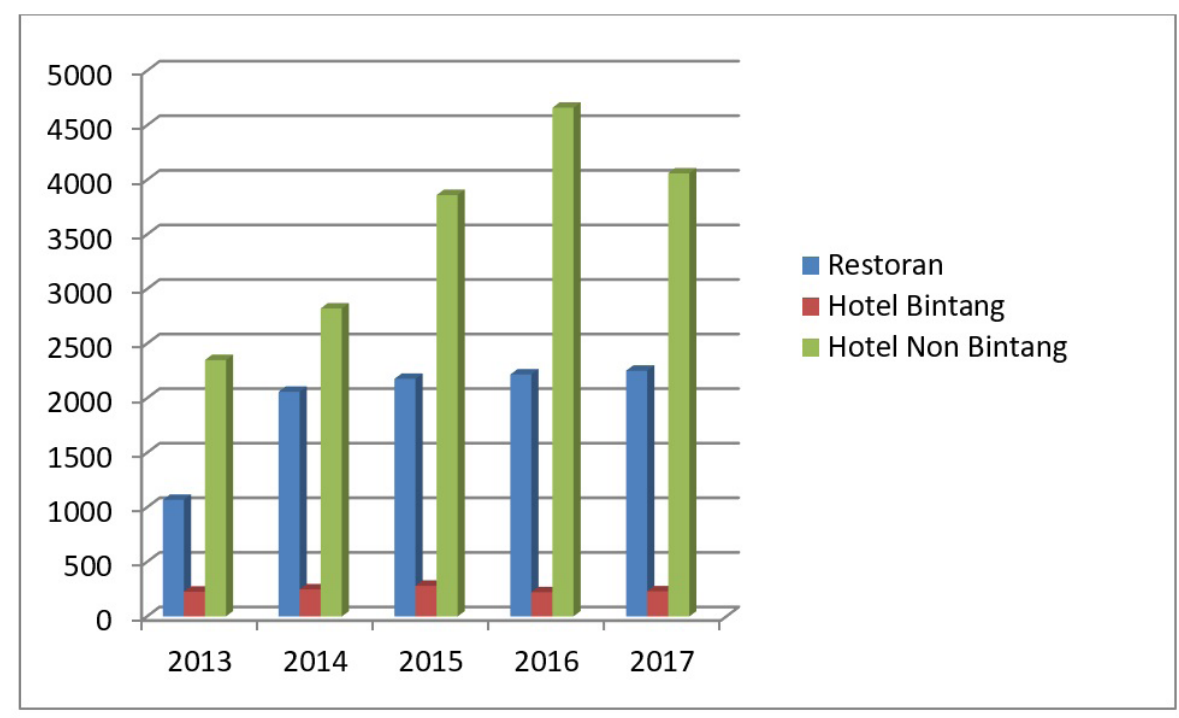

Sumber: Badan Pusat Statistik Provinsi Bali, 2017

dan restoran serta biro perjalanan wisata di Provinsi Bali memberikan prospek dan harapan yang cerah dalam perkembangannya sehingga bermunculan lah berbagai hotel yang diantaranya adalah hotel berbintang dan hotel non bintang, restoran dan biro perjalanan wisata di berbagai kabupaten-kota di provinsi bali seperti telah diuraikan sebelumnya dalam rangka memfasilitasi kedatangan wisatawan mancanegara dan domestic (Suardana, 2017

Adanya hotel dan restoran dan biro perjalanan wisata yang memadai maka wisatawan tak segan kembali berkunjung ke Bali untuk berwisata, dimana kondisi ini tentu akan berpengaruh pula pada perkembangan usaha-usaha di sector pariwisata dan akan berdampak pula terhadap kemampuan bidang pariwisata sebagai salah satu sector andala pada bidang ekonomi dalam rangka meningkatakan kesejahteraan masyarakat dan penciptaan lapangan kerja bagi pencari kerja (Taufik, 2014). Menurut Anuar et al (2011), orang yang meniggalkan rumahnya untuk berekreasi ke dalam arti luas, pariwisata adalah perjalanan dari suatu tempat ketempat lain, yang bersifat sementara dan dilakukan perorangan atau kelompok sebagai usaha mencari keseimbangan atau keserasian dan kebahagiaan dengan lingkungan hidup dalam dimensi sosial, budaya, alam dan ilmu (Spillane, 2002).Anghel (2011) pariwisata internasional merupakan pariwisata yang berorientasi pada kunjungan wisatawan mancanegara dalam konteks globalisasi yang merupakan salah satu penggerak roda perekonomian pada era globalisasi.

Penelitian yang dilakukan Fortanier dan Wijk (2009), tentang Sustainable tourism industry development in sub-Saharan Africa Consequences of foreign hotels for local employment, mengungkapkan bahwa hotel dengan kepemilikan asing memiliki potensi lebih tinggi untuk menciptakan lapangan kerja dibandingkan dengan hotel dengan kepemilikan lokal. Hal ini dikarenakan mereka menawarkan tingkat pelayanan yang lebih tinggi kepada para tamu, sehingga memerlukan lebih banyak staff per kamar. Penelitian lainnya oleh Mbaiwa (2011), tentang Hotel Companies, Proverty And Sustainable Tourism In The Okavango Delta, Botswana, menunjukkan bahwa akomodasi 
Grafik 4.

Jumlah Biro Perjalanan Wisata di Provinsi Bali Pada Tahun 2013-2017

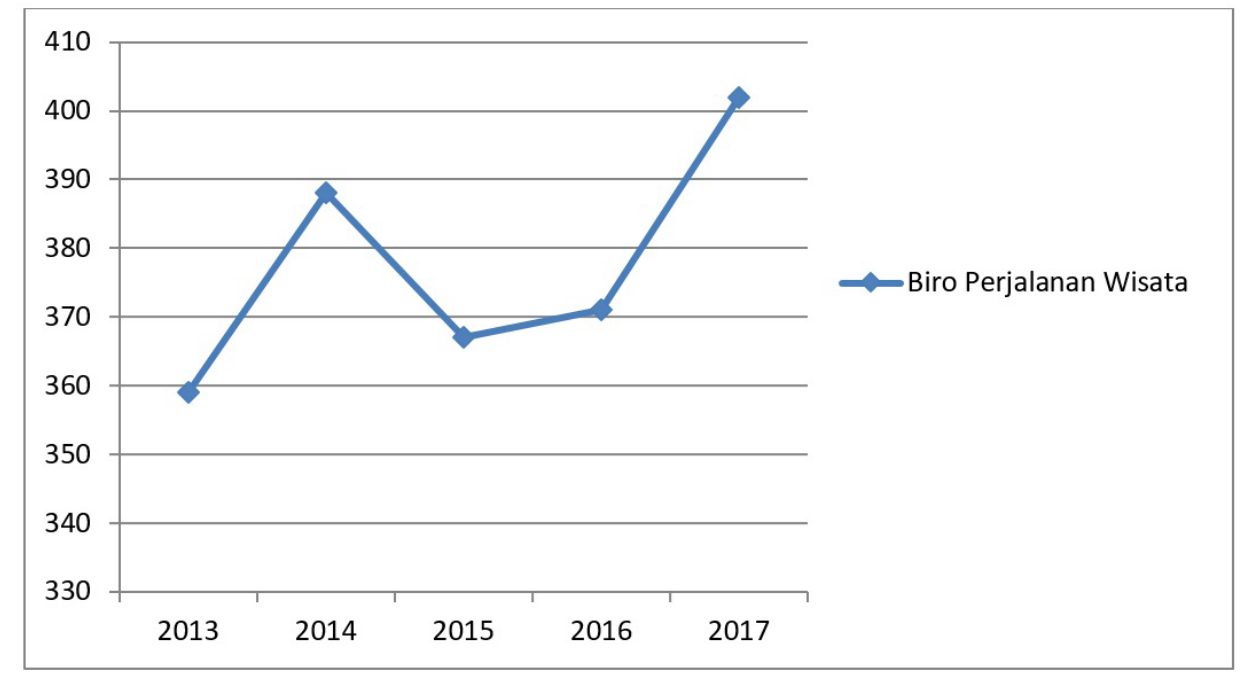

Sumber: Badan Pusat Statistik Provinsi Bali, 2017

hotel berdampak pada ekonomi sosial termasuk penyerapan tenaga kerja, pendapatan dan pembangunan infrastruktur di Okavango Delta, Botswana.

Di seluruh dunia, pariwisata sudah menjadi industri yang sangat besar, dan diproyeksikan tumbuh dengan cepat selama dua dekade ke depan (Anna Both, 1990). Sektor pariwisata sendiri memiliki multiplier effect yang dapat meningkatkan tenaga kerja diluar sektor pariwisata seperti sektor industri, sektor pertanian, dan sektor lainnya, sehingga mampu menciptakan lapangan pekerjaan, peningkatan pendapatan dan kesejahteraan masyarakat, pariwisata muncul sebagai faktor yang mempengaruhi pertumbuhan ekonomi jangka panjang (Gabriel \& Wiston, 2010).Menurut Kuncoro (2002:45) penyerapan tenaga kerja adalah banyaknya lapangan kerja yang sudah terisi yang tercermin dari banyaknya jumlah penduduk bekerja.

Selain sebagai sector andalan dalam pertumbuhan sector perekonomian dalam rangka meningkatkan kesejahteraan dan pendapatan perkapita masyarakat diseluruh kabupaten/kota di Provinsi Bali, sector pariwisata juga diharapkan mampu sebagai penyedia lapangan kerja, dalam menciptakan keseimbangan antara kesempatan kerja dengan pertumbuhan angkatan kerja. Ketidak seimbangan antara pertumbuhan angkatan kerja dan ketersediaan lapangan pekerjaan akan menyebabkan tingginya pengangguran (Cahya Ningsih, 2015). Dalam rangka menciptakan keseimbangan antara pertumbuhan angkatan kerja dengan tersedianya lapangan kerja maka sektor pariwisata harus mampu mendorong tumbuhnya sektor-sektor usaha lainnya seperti sektor usaha akomodasi, restoran dan biro perjalanan wisata.Pengembangan sektor usaha ini sangat penting dilakukan dalam rangka memberikan pelayanan dan kenyamanan bagi wisatawan (Norton, 2002).

Selain dalam rangka memberi layanan dan memfasilitasi kunjungan wisatawan sektorsektor usaha dalam bidang kepariwisataan seprti hotel, restoran dan biro perjalanan wisata juga dapat menyerap tenaga kerja yang banyak dan meningkatkan pendapatan masyarakat.Berkembangnya jumlah restoran yang sama dirasakan di Kota Bandung membuat meningkatkan jumlah restoran yang ada membuat meningkatkan pendapatan yang nantinya akan mematuhi membayar pajak 
restoran yang akan meningkatkan pendapatan asli daerahnya (Dariah dan Yuhka, 2012). Sedangkan menurut J. Mensah-Ansah (2014) di dalam penelitiannya menyimpulkan bahwa besar kecilnya nilai produksi industri berpengaruh positif serta signifikan terhadap penyerapan tenaga kerja.

Menurut Ghofur (2011) hotel merupakan usaha jasa yang padat modal dan padat karya, dalam arti memerlukan modal yang besar dengan jumlah tenaga kerja yang besar pula.Tenaga kerja adalah sebagian penduduk yang dapat menghasilkan barang dan jasa bila terdapat permintaaan terhadap barang dan jasa (Dewi kusumawati, 2012).Penduduk yang bekerja disebut sebagai permintaan atau kebutuhan tenaga kerja (Maryanti, 2012:44). Disamping sebagai penyedia lapangan pekerjaan hotel juga berperan sebagai agen pertumbuhan perekonomian dalam rangkan meningkatkan kesejahteraan masyarakat. karena pengembangan sektorpariwisata pada hakekatnya merupakan interaksi antara proses sosial, ekonomi dan industri. Sehingga menurut Markovic dan Ana (2010) dampak pariwisata terhadap kegiatan dan jasa yang membentuk sektor pariwisata terutama mengacu pada industri hotel, transportasi, perdagangan, kerajinan dan layanan utilitas dimana korelasi yang tinggi dapat ditemukan antara tingkat pengembangan layanan dan pengembangan pariwisata.

Jika pertumbuhan sektor-sektor usaha ini tersebut tumbuh dan berkembang akan mampu menciptakan peluang kerja baru bagi masyarakat, sehingga kondisi ini secara tidak langsung akan mampu pula meningkatkan pendapatan perkapita masyarakatnya (Wellton, 2016). Seperti di katakan oleh Vojnovic dan Knezevic (2013) Kontribusipariwisata bagiperekonomian lokal memberikan dampak ekonomi yang besar untuk kesejahteraan masyarakat setempat (Oroh, 2010).Sebagai daerah tujua wisata dunia apakah perkembangan kepariwisataan di provinsi Bali telah mampu mendorong munculnya usaha-usaha di sektor

Grafik 5.

\section{Penduduk Usia 15 Tahun ke Atas yang Bekerja Menurut Lapangan Usaha di Provinsi Bali, 2013-2017 (orang)}

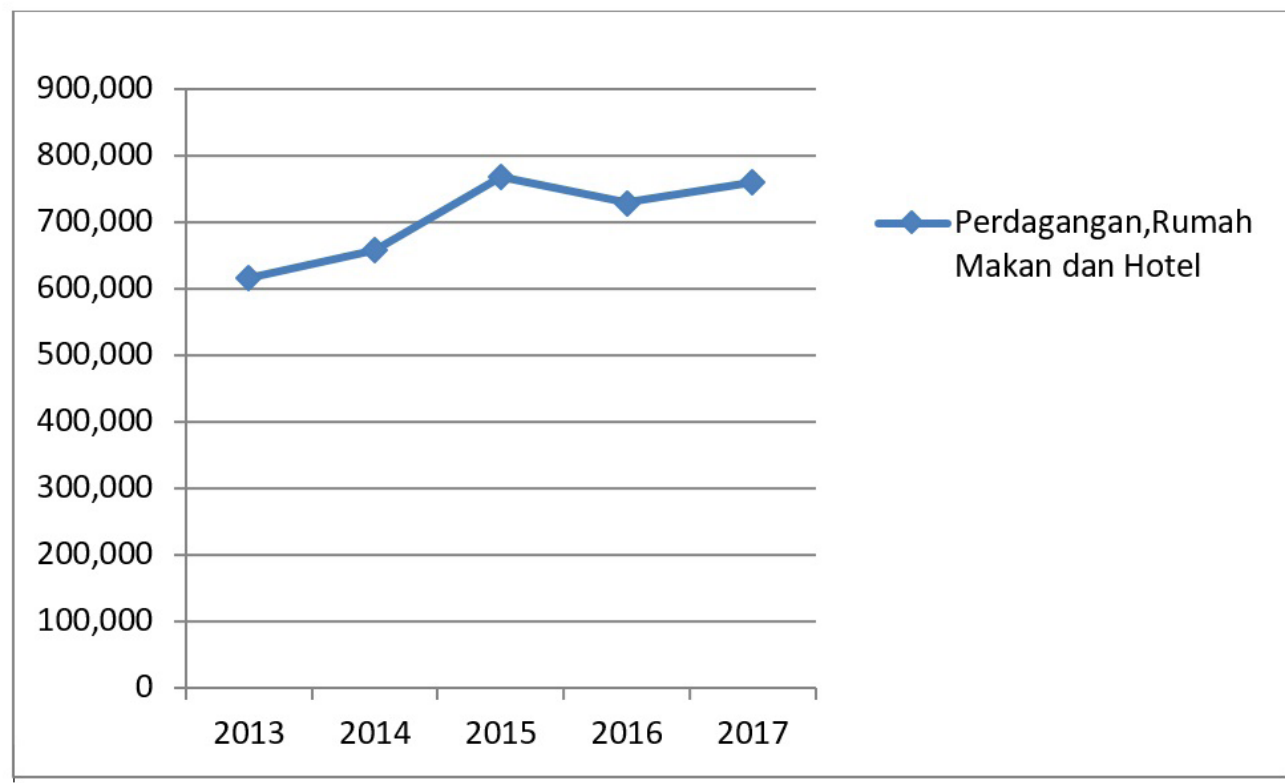

Sumber: Badan Pusat Statistik Provinsi Bali, 2017 
pariwisata diberbagai kabupaten kota yang ada di provinsi bali (Patera, 2009). Yang nantinya mampu menyediakan lapangan kerja dalam rangkamengatasipengangguran danpeningkatan kesejahteraan masyarakat melalui peningkatan pendapatan perkapita masyarakatnya. Sebagai gambaran tentang masyarakat dari usia lima belas (15) tahun keatas yang terserap dan bekerja di sektor pariwisata dalam lima tahun terakhir (2013 -2017) dapat dijelaskan seperti terlihat pada Grafik 5

Berdasarkan grafik tersebut dapat dijelaskan bahwa dalam lima tahun terakhit ini (2013-2017) masyarakat usia lima belas tahun keatas yang bekerja disektor pariwisata menunjukkan kondisi yang berfluktuatif dengan rata-rata pertahunya sebanyak 760.098 orang Berfluktuatifnya penyerapan tenaga kerja di sektor pariwisata tidak terlepas dari berfluktuatifnya pertumbuhan hotel dan restoran yang ada di provinsi Bali.

\section{METODE PENELITIAN}

Adapun lokasi Penelitian ini dilakukan di 8 kabupaten dan 1 kota madya yang ada di provinsi bali. Teknik analisis data yang digunakan untuk memecahkan permasalahan dalam penelitian ini adalah teknik analisis jalur dengan menggunakan IBM SPSS24.Metode analisis yang digunakan pada penelitian ini adalah berbasis jalur (path analysis).

$$
\begin{aligned}
& Y_{1}=b_{1} X_{1}+b_{2} X_{2}+b_{3} X_{3} \\
& Y_{2}=b_{4} X_{1}+b_{5} X_{2}+b_{6} X_{3}+b_{7} Y_{1}+e_{2}
\end{aligned}
$$

Keterangan:

$\mathrm{Y}_{2}=$ Pendapatan Perkapita

$\mathrm{Y}_{1}=$ Penyerapan tenaga kerja Sektor Pariwisata

$\mathrm{X}_{1}=$ Jumlah daya tarik wisata

$\mathrm{X}_{2}=$ Jumlah Hotel dan Restoran

$\mathrm{X}_{3}=$ Jumlah Biro Perjalanan Wisata

$b_{1 \ldots} b_{5}=$ Koefisien regresi untuk masing masing variabel $\mathrm{X}$

$\mathrm{e}_{1,} \mathrm{e}_{2} \quad=$ error term

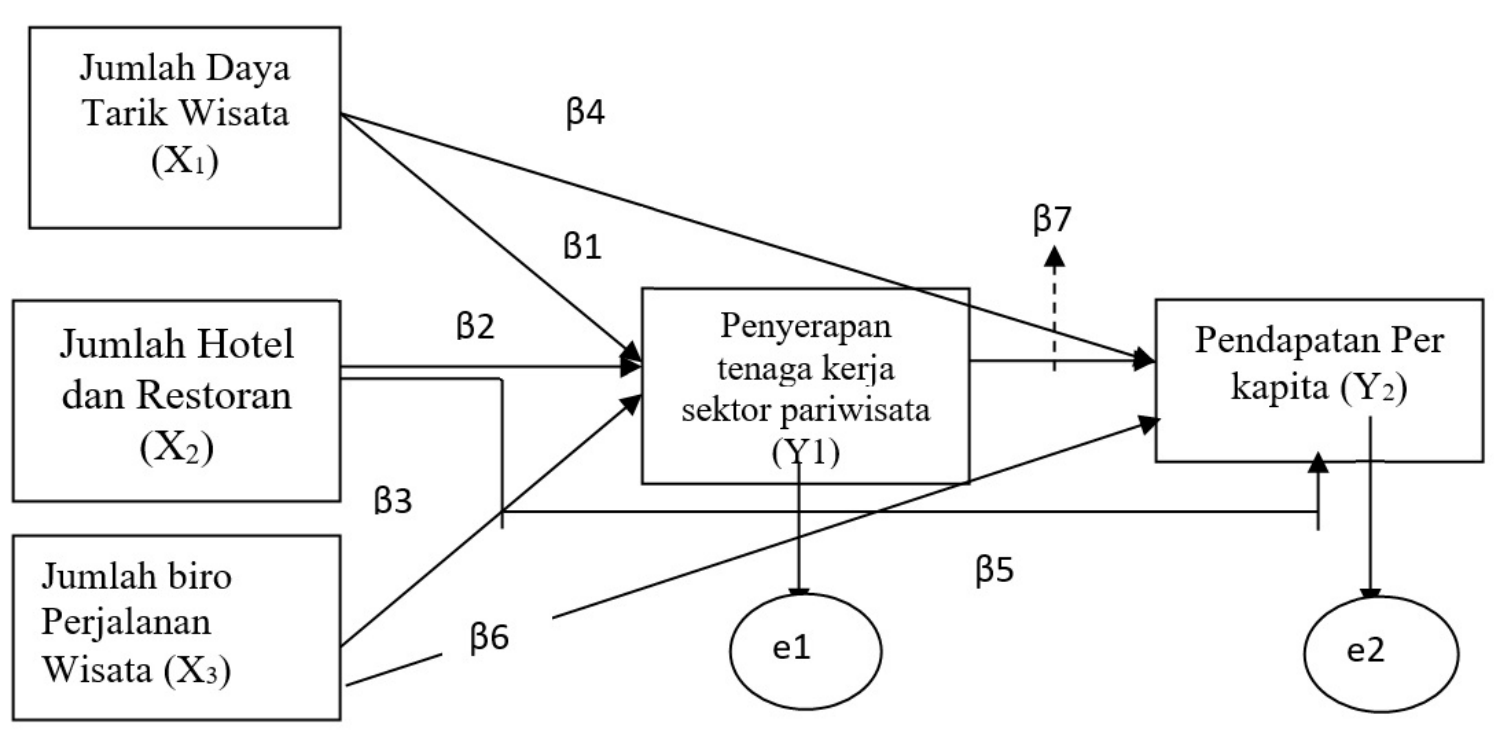

Gambar 1.

Model Analisis Jalur (path analysis) 


\section{HASIL DAN PEMBAHASAN}

Perhitungan koefisien jalur variabel Daya Tarik Wisata (X1), Hotel/ Restoran (X2) dan Biro Perjalanan Wisata Terhadap Vriabel Penyerapan Tenaga kerja (X4/Y1) akan mempergunakan output Coefficient. Selain mempergunakan output Coefficient pada pembahsan kali ini juga akan menggunakan output Model Summary pada persamaan Regresi Model 1, dengan output Coefficients persamaan Regresi Model 1 seperti dapat di lihat pada tabel 1.Selanjutnya output Model Summarynya pada persamaan Regresi Model 1, dapat dilihat pada Tabel 2.

Berdasarkan tabel 2 (output coefficients persamaan regresi model 1) pada kolom Standardized Coefficients maka besarnya masing nilai koefisien jalur untuk variabel Daya Tarik Wisata $\left(\mathrm{X}_{1}\right)$ adalah 0,068 , koefisien jalur variabel Hotel- Restoran sebesar 0,176 dan koefisien jalur variabel Biro Perjalanan Wusata sebesar 0,896.sementara untuk dapat menghitung nilai (e1) terlebih dahulu diketahui nilai R2 atau R Squere . Berpedoman pada tabel
4.13 output Model Summary persamaan Regresi Modell pada kolom R Square dapat diperoleh nilai R Square nya adalah sebesar 0,862 .

Berdasarkan data dan informasi $\mathrm{R}$ Square tersebut maka nilai jalur el dapat dihitung dengan menggunakan rumus :sebagai berikut:

$\mathrm{e} 1=\mathrm{V}(1-\mathrm{R} 2)$

el $=\mathrm{V}(1-0,862)=0,371$, sehingga dengan menggunakan nilai koefisien masing-masing variabel Daya Tarik Wisata $\left(X_{1}\right)$, variabel Hotel Restoran $\left(\mathrm{X}_{2}\right)$ dan variabel Biro Perjalanan Wisata $\left(\mathrm{X}_{3}\right)$ serta nilai koefisien (e1),

Pengujian Hipotesis dan pengaruh secara langsung variabel Daya TarikWisata $\left(\mathrm{X}_{1}\right)$,Variabel Hotel-Restoran $\left(\mathrm{X}_{2}\right)$ dan Variabel jumlah Biro perjalanan Wisata $\left(X_{3}\right)$ terhadap variabel Penyerapan Tenaga Kerja $\left(\mathrm{Y}_{1}\right)$ dalam persamaan regresi model 1 ini akan dilakukan pengujian hipotesis dan pengaruh langsung secara Parsial dan secara bersama-sama atau Simultan.

Pengujian hipotesis pada persamaan regresi model 1 ini dipergunakan out put

Tabel 1.

Output Koefisien Regresi Model 1

\begin{tabular}{llrrrrr}
\hline & \multicolumn{7}{c}{$\begin{array}{c}\text { Standardized } \\
\text { Unstandardized Coefficients } \\
\text { Model }\end{array}$} & & \multicolumn{1}{c}{ Coefficients } & & \\
\hline 1 & B & Std. Error & Beta & \multicolumn{1}{c}{ t } & \multicolumn{1}{c}{ Sig. } \\
\hline & DTW(X1) & 33.591 & 7.349 & & 4.571 & .000 \\
& H\&R(X2) & .252 & .218 & .068 & 1.158 & .044 \\
& BPW(X3) & .025 & .008 & .176 & 2.991 & .005 \\
\end{tabular}

Sumber: Data diolah. 2019

Tabel 2.

OutPut Model Summary Regresi Model 1

\begin{tabular}{lrrrr} 
Model & R & R Square & \multicolumn{1}{c}{$\begin{array}{c}\text { Adjusted R } \\
\text { Square }\end{array}$} & $\begin{array}{l}\text { Std. Error of } \\
\text { the Estimate }\end{array}$ \\
\hline 1 & $.929^{\mathrm{a}}$ & .862 & .852 & 21.89568
\end{tabular}

Sumber: Data diolah. 2019 
persamaan regresi model 1, dimana berdasarkan hasil pengolahan data denganmenggunakan program SPSS diperoleh output coefficients regresinya seperti tabel 4.12 dan berdasarkan tabel tersebut output coefficients persamaan Regresi model 1, yaitu pada kolom Signifikansi, dapat dijelaskan bahwa nilai signifikasi dari ke tiga variabel tersebut yaitu: Daya Tarik Wisata $\left(X_{1}\right),=0,044$, Hotel/Restoran $\left(X_{2}\right)=0,005$ dan Biro Perjalanan Wisata $\left(X_{3}\right)=0,000$, dimana ke tiga variabel tersebut nilai signifikansinya lebih kecil dari 0.05. Hal ini berarti bahwa Regresi Model 1, yakni Variabel Daya Tarik Wisata $\left(\mathrm{X}_{1}\right)$, Variabel Hotel/ Restoran $\left(\mathrm{X}_{2}\right)$, dan Variabel Biro Perjalanan Wisata $\left(\mathrm{X}_{3}\right)$ secara parsial berpengaruh positif dan signifikan terhadap Variabel Penyerapan Tenaga Kerja $\left(\mathrm{Y}_{1}\right)$.

Ada tidaknya pengaruh variabel Daya tarik Wisata (X1), variabel Hotel/Restoran (X2) dan variabel Biro perjalanan Wisata (X3) secara bersama-sama atau secara simultan terhadap Variabel Penyerapan Tenaga Kerja (Y1) akan mengacu pada output model Summary pada tabel 2 dan output ANOVA dengan outputnya seperti disajikan pada Tabel 3 .
Berdasarkan tabel 3 (ANOVA) dapat diketahui nilai Sig. sebesar 0,000 pada kolom Sig, lebih kecil dari 0,05, hal ini berarti bahwa Variabel Daya Tarik Wisata $\left(\mathrm{X}_{1}\right)$, Hotel dan Restoran $\left(\mathrm{X}_{2}\right)$ dan variabel Biro Perjalanan Wisata $\left(\mathrm{X}_{3}\right)$ secara bersama-sama atau secara simultan berpengaruh positif dan signifikan terhadap Penyerapan tenaga kerja $\left(\mathrm{Y}_{1}\right)$.

Jumlah daya tarik wisata, jumlah hotel restoran dan jumlah biro perjalanan wisata berpengaruh positif dan signifikan terhadap penyerapan tenaga kerja sektor pariwisata di kabupaten/kota di Provinsi Bali. maka dengan demikian hipotesis (1) yang diajukan dalam penelitian ini dapat diterima.( artinya meneriman $\mathrm{H} 1$ dan menolak H0 ), selanjutnya mengacu pada tabel 2 ( Model Summary) yaitu pada kolom R Square dimana diperoleh Nilai R Square sebesar 0.862 ini, berarti bahwa kontribusi atau sumbangan pengaruh Variabel Daya Tarik Wisata $\left(\mathrm{X}_{1}\right)$, Hotel dan Restoran $\left(\mathrm{X}_{2}\right)$ dan Variabel Biro Perjanan Wisata $\left(\mathrm{X}_{3}\right)$ secara simultan terhadap variabel Penyerapan Tenaga Kerja $\left(\mathrm{Y}_{1}\right)$ adalah $86,2 \%$ dan sisanya sebesar $13,8 \%$ dipengaruhi oleh factor lain yang tidak

Tabel 3.

Output ANOVA Prsamaan Regresi Model 1

\begin{tabular}{|c|c|c|c|c|c|c|}
\hline Model & & Sum of Squares & df & Mean Square & $\mathbf{F}$ & Sig. \\
\hline \multirow[t]{3}{*}{1} & Regression & 122989.314 & 3 & 40996.438 & 85.512 & $.000^{\mathrm{a}}$ \\
\hline & Residual & 19656.251 & 41 & 479.421 & & \\
\hline & Total & 142645.564 & 44 & & & \\
\hline
\end{tabular}

Sumber: Data diolah. 2019

Tabel 4.

Output Coefficients Regresi Model 2

\begin{tabular}{ccccccc}
\hline \multicolumn{2}{l}{ Model } & \multicolumn{2}{c}{ Unstandardized Coefficients } & $\begin{array}{c}\text { Standardized } \\
\text { Coefficients } \\
\text { Beta }\end{array}$ & Std. Error & Sig. \\
\hline & (Constant) & 28386.511 & 4760.495 & & 5.963 & .000 \\
1 & DTW(X1) & 101.434 & 116.550 & .117 & .870 & .039 \\
& H\&R(X2) & 1.918 & 4.869 & .057 & .394 & .006 \\
& BPW(X3) & 29.029 & 60.138 & .165 & .483 & .032 \\
& TKS(Y1/X4 & 99.569 & 82.338 & .424 & 1.209 & .034 \\
\hline
\end{tabular}

Sumber: Data diolah. 2019 
Tabel 5.

Output Model Summary persamaan Regresi Model 2

\begin{tabular}{|c|c|c|c|c|}
\hline Model & $\mathbf{R}$ & R Square & Adjusted R Square & Std. Error of the Estimate \\
\hline 1 & $.569^{\mathrm{a}}$ & .323 & .256 & 11543.79000 \\
\hline
\end{tabular}

Sumber: Data diolah. 2019

diteliti dalam penelitian ini.Perhitungan nilai koefisien jalut pengaruh langsung variabel Daya Tarik Wisata $\left(\mathrm{X}_{1}\right)$ variabel Hotel dan Restoran $\left(\mathrm{X}_{2}\right)$, variabel Biro Perjalanan Wisata (3) dan variabel Penyerapan Tenaga Kerja ( $\mathrm{Y}_{1} /$ $\mathrm{X}_{4}$ ) terhadap variabel Pendapatan perkapita $\left(\mathrm{Y}_{2}\right)$ pada pembahasan ini dipergunakan output persamaan Regresi Model 2 dengan output Coeffisients seperti Tabel 4 dan output Model Summary seperti Tabel 6.

Adapun output Model Summarnya persamaan regresi model 2 dapat dilihat seperti pada tabal 5.

Berdasarkan tabel 5 pada kolom standardized Coefficients maka di peroleh besarnya nilai koefisien jalur untuk variabel Daya Tarik Wisata(X1) sebesar 0,117, Variabel Hotel/ Restoran(X2) sebesar 0,057, Variabel Biro Perjalanan Wisata sebesar 0,165 dan Variabel Penyerapan Tenaga Kerja (Y1/ X4) sebesar 0.424, sementara untuk dapat menentukan niali koefisien (e2) terlebeih dahulu diketahui besarnya nilai R Squarenya . Mengacu pada tabel 4.16 output Model Summary dapat diperoleh nilai R2 atau R Square sebesar 0,323 seperti terlihat pada kolom R Square pada tabel 4.16 , maka berdasarkan output Coefficients dan output Model Summary tersebut dapat dihitung besarnya nilai koefisien (e2) dengan Rumus:

e2 $=\sqrt{ }((1-R 2))$ sehingga nilai koefisien e $2=\sqrt{ }(1-$ $0.323)=0,822$. sehingga dengan mengunakan nilai koefisien masing-masing variavel Daya Tarik wisata $\left(\mathrm{X}_{1}\right)$, variabel Hotel dan Restoran $\left(\mathrm{X}_{2}\right)$, variabel Biro Perjalanan Wisata(X3) ,variabel Penyerapan Tenaga Kerja(Y1/X4) dan nilai koefisien (e2) pada persamaan jalur regresi model2 dan nilai koefisien ( $\mathrm{X} 1, \mathrm{X} 2$,
$\mathrm{X} 3$ dan e1) pada persamaan jalur regresi model 1.Pengujian Hipotesis dan pengaruh langsung variabel Daya Tarik Wisata $\left(\mathrm{X}_{1}\right)$, Variabel Hotel dan Restoran $\left(X_{2}\right)$ dan Variabel Biro perjalanan Wisata $\left(X_{3}\right)$ dan variabel Penyerapan Tenaga Kerja $\left(Y_{1} / X_{4}\right)$ terhadap Pendapatan Perkapita $\left(Y_{2}\right)$ dalam persamaan regresi model 2 ini juga akan dilakukan pengujian hipotesis dan pengaruh langsung secara Parsial dan Simultan.

Menguji hipotesis dan melihat pengaruh langsung analisis jalur dengan persamaan regresi model 2 dipergunakan out put regresi model 2 Berdasarkan hasil pengolahan data dengan program SPSS (seperti pada lampiran 4 output persamaan regresi model2) diperoleh output Coefficients regresinya seperti tabel 5 tersebut dan .dengan menggunakan output Coefficients tabel tersebut pada persamaan Regresi model 2.

Untuk menguji ada tidaknya pengaruh langsung variabel Daya tarik Wisata $\left(\mathrm{X}_{1}\right)$, variabel Hotel Restoran $\left(X_{2}\right)$ dan variabel Biro perjalanan Wisata $\left(X_{3}\right)$ serta variabel Penyerapan Tenaga Kerja $\left(Y_{1} / X_{4}\right)$ secara bersama-sama atau secara simultan terhadap Variabel Pendapatan Perkapita $\left(\mathrm{Y}_{2}\right)$ maka akan di pergunakan output regresi persamaan 2 pada (lampiran 4 output persamaan regresi model2) yaitu berupa output model Summary pada tabel 5 dan output ANOVA pada tabel 6.

Berdasarkan tabel 6 (output ANOVA) dapat diketahui nilai Sig. sebesar 0,003 pada kolom Sig, lebih kecil dari 0,05, hal ini berarti bahwa Variabel Daya Tarik Wisata $\left(X_{1}\right)$, variabel Hotel dan Restoran $\left(\mathrm{X}_{2}\right)$ variabel Biro Perjalanan Wisata $\left(\mathrm{X}_{3}\right)$ dan variabel Penyerapan Tenaga Kerja ( $\left.\mathrm{Y}_{1} / \mathrm{X}_{4}\right)$ secara bersama-sama atau 
Tabel 6.

Output ANOVA Persamaan Regresi Model2

\begin{tabular}{llrrrrr}
\hline Model & & Sum of Squares & Df & Mean Square & F & Sig. \\
\hline 1 & Regression & $2.547 \mathrm{E} 9$ & 4 & $6.369 \mathrm{E} 8$ & 4.779 & $.003^{\mathrm{a}}$ \\
& Residual & $5.330 \mathrm{E} 9$ & 40 & $1.333 \mathrm{E} 8$ & & \\
& Total & $7.878 \mathrm{E} 9$ & 44 & & & \\
\hline
\end{tabular}

Sumber: Data diolah. 2019

secara simultan berpengaruh signifikan terhadap Pendapatan Perkapita $\left(\mathrm{Y}_{2}\right)$. Berdasarkan analisis dan kesimpulan tersebutmaka hipotesis ke 2 yang telah diajukan sebelumnya dapat diterima. (berarti menerima hipotesis H1 dan menolak H0 )Selanjutnya mengacu pada tabel 5 ( Model Summary) yaitu pada kolom R Square dimana diperoleh 1 Nilai R Square sebesar 0.323 ini, berarti bahwa kontribusi atau sumbangan pengaruh Variabel Daya Tarik Wisata $\left(\mathrm{X}_{1}\right)$, variabel Hotel dan Restoran $\left(\mathrm{X}_{2}\right)$, Variabel Biro Perjanan Wisata $\left(\mathrm{X}_{3}\right)$ dan variabel Penyerapan Tenaga Kerja $\left(\mathrm{Y}_{1} / \mathrm{X}_{4}\right)$ secara bersama-sama atau secara simultan terhadap variabel Pendapatan Perkapita $\left(\mathrm{Y}_{2}\right)$ adalah $32,3, \%$ dan sisanya sebesar $66,7 \%$ dipengaruhi oleh factor lain yang tidak diteliti dan dibahas dalam penelitian ini.

Pengaruh langsung variabel Daya Tarik Wisata(X1) terhadap variabel Pendapatan Perkapita (Y2) sebesar 0,117 dan pengaruh tidak langsung variabel Daya Tarik wisata (X1) terhadap variabel Pendapatan Perkapita(Y2) melalui variabel Pendapatan Perkapita (Y1/X4) sebesar 0,029, hal ini berarti nilai pengaruh tidak langsung variabel Daya Tarik Wisata (X2) terhadap variabel pendapatan perkapita (Y2) melalui variabel Penyerapan Tenaga Kerja (Y1/ $\mathrm{X} 4)$ lebih kecil dari pengaruh langsung variabel Daya Tarik Wisata (X1) terhadap Pendapatan Perkapita(Y2), maka dengan demikian dapat disimpulkan bahwa pengaruh Variabel Daya Tarik Wisata (X1) terhadap variabel Pendapatan Perkapita (Y2) melalui variabel Penyerapan Tenaga Kerja adalah berpengaruh tapi besar pengaruhnya Tidak signifikan, maka dengan demikian hipotesis yang diajukan di tolak.
Pengaruh langsung variabel Hotel dan Restoran (X2) terhadap variabel Pendapatan Perkapita (Y2) adalah sebesar 0,057, sedangkan nilai pengaruh tidak langsung variabel Hotel dan Restoran (X2) terhadap variabel Pendapatan Perkapita (Y2) melalui Penyerapan tenaga kerja (Y1/X4) adalah sebesar 0,075, hal ini berarti nilai pengaruh tidak langsung variabel Hotel dan Restoran (X2) terhadap variabel Pendapatan Perkapita( Y2) melalui Veriabel Penyerapan Tenaga Kerja (Y1/X4) lebih besar dari nilai pengaruh langsung variabel Hotel dan Restoran terhadap variabel Pendapatan Perkapita (Y2). Maka dengan demikian dapat disimpulkan bahwa pengaruh tidak langsung variabel Hotel dan Restoran (X2) terhadap variabel Pendapatan Perkapita (Y2) melalui variabel penyerapan Tenaga Kerja (Y1/X4) adalah berpengaruh dengan pengaruh yang signifikan.maka dengan demikian hipotesis yang diajuakan dapat diterima.

Biro Perjalanan Wisata (X3) terhadap variabel Pendapatan Perkapita(Y2) yaitu sebesar 0,165 sedangkan nilai pengaruh tidak langsung variabel Biro Perjalanan Wisata (X3) terhadap variabel Pendapatan Perkapita(Y2) melalui variabel Penyerapan Tenaga Kerja $\left(\mathrm{Y}_{1} / \mathrm{X}_{4}\right)$ adalah sebesar $\mathbf{0 , 3 8 0}$, maka hal ini berarti nilai pengaruh tidak langsung variabel Biro Perjalanan Wisata (X3) terhadap variabel pendapatan perkapita (Y2) melalui variabel Penyerapan Tenaga Kerja (Y1/X4) lebih besar dari pada nilai pengaruh langsung variabel Biro Perjalanan Wisata (X3) terhadap Pendapatan Perkapita (Y2) ,sehingga dengan demikian dapat disimpulkan bahwa "pengaruh Variabel Biro Perjalanan Wisata (X3) terhadap variabel 
Pendapatan Perkapita (Y2) melalui variabel Penyerapan Tenaga Kerja (Y1/X4) adalah berpengaruh dengan pengaruh yang signifikan, maka dengan demikian hipotesis yang diajukan dapat diterima.

Untuk menguji hipotesis pengaruh tidak langsung variabel Daya tarikWisata (X1), Hotel dan Restoran (X2) dan variabel Biro Perjalanan Wisata (3) terhadap variabel Pendapatan Perkapita(Y2) melalui variabel Penyerapan Tenaga Kerja(Y1/X4) juga dipergunana Uji Sobel dengan rumusnya sebagai berikut:

Dimana :

$$
\mathrm{Sab}=\sqrt{b^{2} S a^{2}+a^{2} S b^{2}+S a^{2} S b^{2}}
$$

Koefisien direct effect X1,X2 dan X3 Terhadap $\mathrm{Y} 1 / \mathrm{X} 4$.

Koefisien direct effect Y1/X4 terhadap Y2.

Sa. Standar error dari koefisien a

$\mathrm{Sb}$. Standar error dari koefisien $b$.

$\mathrm{Z}$ test $=\frac{a b}{S a b}$

Untuk pengujuan hipotesis pengaruh tidak langsung variabel Daya Tarik Wisata (X1), HotelRestoran (X2) dan Variiabel Biro Perjalanan Wisata (X3) terhadap Variabel Pendapatan Perkapita (Y2) melalui variabel Penyerapan Tenaga kerja (Y1/X4) ,maka pengujian hipotesisnya akan dilakukan secara Pasial dengan menggunakan output Unstandardized coefficients regresi model 1 dan regresi model 2 seperti Tabel 7
Perhitungan nilai Sobel test dan nilai $Z$ test dapat dicari dengan menggunakan Rumus Sobel test dan rumus $Z$ test seperti tersebut dengan rumus perhitungaannya sebagai berikut

$$
\mathrm{Sab}=\sqrt{b^{2} S a^{2}+a^{2} S b^{2}+S a^{2} S b^{2}}
$$

Keterangan:

Koefisien direct effect X1,Terhadap Y1/X4.

Koefisien direct effect Y1/X4 terhadap Y2.

Sa. Standar error dari koefisien a (X1 Terhadap $\mathrm{Y} 1 / \mathrm{X} 4)$

$\mathrm{Sb}$. Standar error dari koefisien b (Y1/X4 terhadap Y2)

$$
\begin{aligned}
\mathrm{Sab}= & =\sqrt{\left.\left(99,569^{2} \times 0,218^{2}\right)+\left(0,252^{2} \times 82,338^{2}\right)+0,218^{2} \times 82,338^{2}\right)} \\
= & \sqrt{9913,99 \times 0,047)+(0,063 \times 6779,54)+(0,047 \times 6779,54)} \\
= & \sqrt{4665,957+427,111+318,638} \\
= & \sqrt{1215,70}=34,86 \\
Z \text { tes sab }= & =\frac{a x b}{S a b} \\
= & \frac{0,252 \times 99,569}{34,86} \\
& =\frac{25,091}{34,86}=0,719
\end{aligned}
$$

Berdasarkan hasil uji Sobel-test dan Z-test tersebut diperoleh nilai $Z$-testnya sebesar $0,719<\mathrm{Z}$ tabel yaitu 1,96 . selanjutnya mengacu pada hipotesis (3) yang diajukan yaitu: "Jumlah

\begin{tabular}{|c|c|c|c|c|c|}
\hline \multirow{2}{*}{\multicolumn{2}{|c|}{ Model }} & \multicolumn{3}{|c|}{ Unstandardized Coefficients } & \multirow[b]{2}{*}{ Sig } \\
\hline & & B & Std Error & $\mathbf{t}$ & \\
\hline 1 & Daya Tarik Wisata (X1) & 0,252 & 0,218 & 1,158 & 0,044 \\
\hline 1 & Hotel dan Restoran(X2) & 0,025 & 0,008 & 2,991 & 0,005 \\
\hline 1 & Biro Perjalanan Wisara(X3 & 0,673 & 0,044 & 15,171 & 0,000 \\
\hline 2 & Penyerapan Tenaga Kerja(Y1/X4) & 99,569 & 82,338 & 1,209 & 0,034 \\
\hline
\end{tabular}
daya Tarik Wisata (X1) berpengaruh secara tidak langsung terhadap variabel Pendapatan Perkapita (Y2) melalui variabel Penyerapan Tenaga Kerja (X1/X4)" . Oleh karena nilai Z-hitung yang diperoleh yaitu sebesar 0,719< dari Z-tabel 1.96 ,yang artinya terdapat pengaruh

Tabel 7.

Output Unstandardized Coefficient Regresi Model 1 dan 2

Sumber: Data diolah. 2019 
tidak langsung variabel Daya Tarik Wisata (X1) terhadap variabel Pendapatan Perkapita(Y2) melalui variabel Penyerapan Tenaga (Y1/X4) tetapi pengaruhnya tidak signifikan. Sehingga hipotesis yang diajukan dalam uji ini ditolak, Hal ini berarti pula bahwa variabel Penyerapan tenaga Kerja (Y1/X4) tidak signifikan sebagai variabel dapat dihitung nilai Sobel-test dan nilai Z-testnya seperti peritungan berikut ini.

$\mathrm{Sab}=\sqrt{b^{2} S a^{2}+a^{2} S b^{2}+S a^{2} S b^{2}}$

keterangan:

Koefisien direct effect, X2 Terhadap Y1/X4

Koefisien direct effect $\mathrm{Y} 1 / \mathrm{X} 4$ terhadap $\mathrm{Y} 2$

Sa. Standar error dari koefisien a ( X2 terhadap Y1/X4 )

Sb. Standar error dari koefisien b ( Y1/X4 terhadap Y2 ).

$$
\begin{aligned}
\text { Sab } & =\sqrt{\left(99,569^{2} \times 0,008^{2}\right)+\left(0,025^{2} \times 82,338^{2}\right)+\left(0,008^{2} \times 82,338^{2}\right)} \\
& =\sqrt{9913,99 \times 0,00064)+(0,00625 \times 6779,55)+(0,000064 \times 6779,55} \\
& =\sqrt{0,63445+4,23722+0,43389} \\
& =\sqrt{5,30556} \\
& =2,30338 \\
Z \text { test } & =\frac{a x b}{S a b} \\
& =\frac{0,025 \times 99,569}{2,30338} \\
& =\frac{2,489225}{2,30338}=1,08068
\end{aligned}
$$

Berdasarkan hasil perhitungan tersebut diperoleh hasil Z-hitungnya sebesar 1,08068 ,dimana hasil Z-hitungnya lebih kecil dari Z-tabel yaitu 1.96 ,artinya terdapat pengaruh tidak langsung Variabel Hotel - Restoran(X2) terhadap Variabel Pendapatan per Kapita(Y2) melalui variabel Penyerapan Tenaga Kerja(Y1/ X4), tetapi pengaruhnya tidak signifikan. Dan ini berarti pula bahwa variabel Penyerapan tenaga Kerja (Y1/X4) tidak signifikan sebagai variabel mediasi,.Sehingga dengan demikian Hipotesis (3) yang diajukan pada bab sebelumnya yaitu "Jumlah Hotel dan restoran (X2) berpengaruh secara tidak langsung terhadap variabel Pendapatan per Kapita (Y2) melalui variabel Penyerapan tenagakerja (Y1/X4), tidak dapat diterima atau ditolak.

Maka secara manual besarnya nilai Sobel-tes dan nilai Z-test dapat dihitung dengan menggunakan rumus seperti berikut ini.

$\mathrm{Sab}=\sqrt{b^{2} S a^{2}+a^{2} S b^{2}+S a^{2} S b^{2}}$

Keterangan:

Koefisien direct effect X3 Terhadap Y1/X4

Koefisien direct effect Y1/X4 terhadap Y2

Sa. Standar error dari koefisien a ( X3 terhadap $\mathrm{Y} 1 / \mathrm{X} 4$ )

Sb. Standar error dari koefisien b ( Y1/X4 terhadap Y2 ).

$$
\begin{aligned}
\text { Sab } & =\sqrt{\left(99,569^{2} \times 0,044^{2}\right)+\left(0,673^{2} \times 82,338^{2}\right)+\left(0,044^{2} \times 82,338^{2}\right)} \\
& =\sqrt{9913,99 \times 0,00194)+(0,45293 \times 6779,55)+(0,00194 \times 6779,55)} \\
& =\sqrt{19,2331+3070,66+13,152} \\
& =\sqrt{3103,045}=55,704 \\
Z \text { tes } & =\frac{a x b}{\operatorname{Sab}} \\
& =\frac{0,673 \times 99,569}{55,704} \\
& =\frac{67,009}{55,704}=1,2029
\end{aligned}
$$

Hasil perhitungan pengaruh tidak langsung variabel Biro Perjalanan Wisata (X3) terhadap variabel Pendapatan Perkapita (Y2) melalui variabel Penyerapan Tenaga kerja (Y1/ X4) diperoleh nilai Z-test sebesar 1,2029< dari nilai Z-tabel yaitu 1.96 , hal ini berarti bahwa terdapat pengaruh tidak langsung variabel Biro Perjalanan Wisata (X3) terhadap variabel Pendapatan perkapita(Y2) melalui variabel Penyerapan tenaga Kerja (Y1/X4) dengan pengaruh yang tidak signifikan,,dan hal ini berarti pula bahwa variabel Penyerapan tenaga Kerja (Y1/X4) tidak signifikan menjadi variabel mediasi dalam hubungan tidak langsung ini, sehingga Hipotesis (3) yang telah diajukan 
yaitu : Jumlah Biro Perjalanan Wisata (X3) berpengaruh secara tidak langsung terhadap variabel Pendapatan Perkapita (Y2) melalui variabel Penyerapan Tenaga Kerja (Y1/X4) tidak dapat diterima atau di Tolak.

Berdasarkan analiasis Sobel-test dan Z-test yang dipergunakan , untuk menguji hipotesis pengaruh tidak langsung ketiga variabel independen (X1, X2, dan X3) tersebut terhadap Variabel Pendapatan Perkapita(Y2) melalui variabel Penyerapan Tenaga Kerja (Y1/X4) adalah dengan pengaruh yang tidak signifikan , karena Nilai Z-hitung dari masingmasing ketiga variabel $(\mathrm{X} 1, \mathrm{X} 2$, dan $\mathrm{X} 3)$ yang diperoleh < dari pada Z-tabel yaitu 1.96, sehingga hipotesis (3) yang diajukan di Tolak, ini berarti variabel penyerapan Tenaga Kerja (Y1/ X4) tidak signifikan menjadi variabel moderasi pengaruh tidak lansung variabel Independen (X1, X2,dan X3) terhadap variabel Pendapatan Perkapita (Y2) pada uji Sobel-test dan uji Z-test yang dilakukan.

\section{SIMPULAN DAN SARAN}

Berdasarkan hasil uji secara parsial pengaruh langsung variabel jumlah Daya tarik Wisata (X1) jumlah Hotel-Restoran(X2) dan variabeljumlah Biro Perjalanan Wisata (X3) terhadap variabel Penyerapan Tenaga kerja sektor pariwisata (Y1/X4) ternyata kontribusi variabel jumlah Daya Tarik Wisata (X1) memiliki kontribusi yang paling kecil dalam hal penyerapan jumlah tenaga kerja diantara ke dua variabel tersebut (X1 dan X2) dengan nilai koefisien betanya hanya sebesar 0,068 , Agar Daya tarik wisata mampu menyediakan lapangan kerja dan menyerap tenaga kerja yang lebih banyak,maka pihak-pihak pemangku kewenangan seperti pemerintah ditingkat Provinsi, Kabupaten-Kota, kecamatan, desa-desa adat perlu membuat regulasi bersama dalam rangka lebih memberdayakan masyarakat dalammengelola daya tarik wisata yang ada dilingkungannya,sehingga kapasitas daya tarik wisata dalam menyerap tenaga kerja lebih maksimal. Dilihat dari pengaruh langsung variabel $(\mathrm{X} 1, \mathrm{X} 2, \mathrm{X} 3$ dan $\mathrm{Y} 1 / \mathrm{X} 4)$ terhadap variabel Pendapatan Perkapita (Y2) ternyata kontribusi variabel Hotel-Restoran memliki kontribusi yang paling kecil terhadap pertumbuhan pendapatan perkapita(Y2) dengan nilai koefisien betanya hanya 0,057 , pada hal yang kita tahu bahwa di kabupaten kota di provinsi bali banyak beroperasi hotelrestoran yang bertaraf internasiaonal. hotelrestoran yang ada di kabupaten kota di Provinsi Bali dapat berkontribusi lebih maksimal terhadap pertumbuhan pendapatan perkapita di Kabupaten-Kota di Provinsi Bali perlu ada regulasi yang dibuat oleh pemerintah Provinsi atau pemerintah Kabupaten Kota, dalam bentuk regulasi pengembangan potensi wisata yang di miliki oleh masing-masing kabupaten/kota di Provinsi Bali sehingga akan tercipta peluang kerja bagi masyarakat Bali.

\section{REFERENSI}

Anghel, Daniela. 2011. Development and Diversification of Tourism Services. A Strategic Approach in International Context. European Journal of Tourism Research, 4(1), pp: 75-77.

Anuar, Ahmad Nazrin Aris., Ahmad, Habibah., Jusoh, Hamzah., and Hussain, Mohd Yusof. 2012. The Roles of Tourism System towards Development of Tourist Friendly Destination Concept. Asian Social Science, 8(6), pp:146-155.

Artana Yasa, I Komang Oka dan Sudarsana Arka. 2015. Pengaruh Pertumbuhan Ekonomi dan Disparitas Pendapatan Antar Daerah Terhadap Kesejahteraan Masyarkat Provinsi bali. Jurnal Ekonomi Kuantitatif Terapan. Volume 8 Nomor 1

Badan Pusat Statistik Provinisi Bali. 2018. Statistic of Bali, Bali Dalam Angka. Denpasar

Bendesa, I.K.G dan I Made Sukarsa. 2012. An Economic Survey Of Bali. Bulletin Of Indonesian Economic Studies.Volume 
16.Issue 2.

Dariah, Atih Rohaeti; Sundaya, Yuhka. Pengaruh Perkembangan Sektor Perdagangan, Hotel Dan Restoran Kota Bandung Terh-adap Sektor Pertanian Daerah Lainnya di Jawa Barat. Jurnal Ekonomi Kuantitatif Ter-apan, [S.l.], oct. 2012.

Dewi Kusumawati, Ni Luh Putu. Analisis variabel-variabel yang mempengaruhi tingkat upah riil di Indonesia tahun 1992-2010 ( PendekatanSimultaneous Regression) Pira-mida.

Dinas Pariwisata Provinsi Bali. 2018. Statistik Kepariwisataan 2018. Bali: Dinas Pariwisata Provinsi Bali

Ekanayake and E.Long, Aubrey. 2012. Tourism Development and Economic Growth in Developing Countries. The International Journal of Business and Finance Research, 6(1): pp: 61-63.

Gabriel Brida Juan \& Wiston Adrian Risso. 2010. Tourism as a determinant of longrun economic growth. Journal Of Policy Research in Tourism, Leisure and Events. 2:1, 14-28.

Ghofur, Abdul. 2011. Pengaruh Fasilitas Hotel Terhadap Penyerapan Tenaga Kerja Di Kecamatan Pacel.Jurnal UNISLA, 2, pp: 1-7.

J. Mensah-Ansah, Dr. 2014. Small tourism accommodation business owners in Ghana: a factor analysis of motivations and challenges, African Journal of Hospitality, Tourism and Leisure, 3 (1): h: 1-17

Kamal, Mostafa dan Shah Alam Kabir Paramanik. 2015. Identifying Factors Influencing Visitor Visitor to Visit Museum in Bangladesh and Setting Marketing Strategies For Museums. IOSR Journal Of Business And Management Vol 17 Issue 10.

Kibara, N. Obidah, Odhiambo, M. Nicholas, and Njuguna, M. Joshepine. 2012. Tourism And Economic Growth In Kenya: An Empirical Investigation. University of South Africa, South Africa.International
Business \& Economics Research Journal.Vol. 11.No. 5.

Markovic, Ana Tripkovic, MSc.2010. Tourism. Planning. : Contributions off Tourisms tos Socios-seconomicd Developmentu off Montenegro. Dalam Jurnal Biennial International Congress 1289-1304.

Maryanti, Sri. 2012. Analisis Perencanaan Tenaga Kerja Terhadap Kebutuhan Tenaga Kerja Di Provinsi Riau Tahun 2006 2010, Pekbis Jurnal 4.(1): 54-62

Mbaiwa, Joseph, E. 2011. Hotel Companies. Proverty and sustainable tourism in the okavango delta, bostwana, world journal of entrepreneurship, management and sustainable development 7 (1): 47 58.

Nicely, Annmarie, and Palakurthi, Radesh. 2012. Navigating Through Tourism Option: an Island Perspective. International Journal of Culture, Tourism and Hospitality Research, 6 (2), PP: 133-144

Ningsih, Ni Made Cahya; Indrajaya, I Gst. Bagus. Pengaruh Modal Dan Tingkat Upah Terhadap Nilai Produksi Serta Penyerapan Tenaga Kerja Pada Industri Kerajinan Perak. Jurnal Ekonomi Kuantitatif Terapan, [S.1.], nov. 2015. ISSN 23030186.

Nursyamsi.2015. Hubungan Kausalitas Antara Jumlah Kunjungan Wisatawan dan Produk Domestik Regional Bruto (PDRB) Sulawesi Selatan. Jurnal Ilmiah.Fakultas Ekonomi dan Bisnis Universitas Brawijaya Malang.lac

Oroh, Sem George. 2010. Pengaruh Fasilitas Daya Tarik Wisata Terhadap Kepuasan Serta Loyalitas Wisatawan yang Berkunjung Ke Provinsi Sulawesi Utara.Jurnal Kepariwisataan Indonesia, (5)4, h:411430.

Pleanggra, Ferry dan Edy Yusuf A.G 2012, Analisis Pengaruh Jumlah Obyek Wisata, Jumlah Wisatawan dan Pendapatan Perkapita Terhadap Pendapatan Retribu- 
si Obyek Pariwisata 35 Kabupaten/Kota di Jawa Tengah. Diponegoro journal of economic Volume 1, Nomor 1,

Rukini, Rukini; Simpen Arini, Putu; Nawangsih Esthisatari. Peramalan Jumlah Kunjungan Wisatawan Mancanegara (Wisman) Ke Bali Tahun 2019: Metode ARIMA. Jurnal Ekonomi Kuantitatif Terapan, [S.1.], nov. 2015. ISSN 2303-0186.

Samimi, Ahmad Jafari. 2011. Tourism and Economic Growth in Developin Countries: P-Var Approch. Middle East Journal of Scientific Research 10(1):28-32

Setyadhi Mustika, Made Dwi. 2012. Investasi swasta sektor pariwisata dan penyerapan tenaga kerja di Provinsi Bali. (Sebuah Analisis Tipologi Daerah). Input Jurnal Ekonomi dan Sosial.

Suardana, I Wayan. 2017. Pemberdayaan perempuan di kawasan kuta sebagai upaya peningkatan kualitas pariwisata bali. Piramida.

Taufik, Muhammad,.Rochaida, Eni dan Fitriadi.2014. Pengaruh Investasi dan Ekspor Terhadap Pertumbuhan Ekonomi Serta Penyerapan Tenaga Kerja Provinsi Kalimantan Timur Periode 2003-2011.Jurnal Ekonomi Kuantitatif Terapan.Volume 7.Nomor 2. ISSN: 2301-8968.

Vojnovic, Nikola. And Knezevic, Rade. 2013. Economic And Tourism Indicator as a Menas of Monitoring Sustanaible Tourism: The Case Of Inland Istria. UTMS Journal of Economics, 4(2), pp:213-230 